\title{
TÉRSÉGI INNOVÁCIÓ VAGY PERIFERIZÁLÓDÁS
}

\author{
Rechnitzer J. (1993) Szétszakadás vagy felzárkózás. \\ A térszerkezetet alakító innovációk. MTA RKK, Györ. 208 o.
}

Egy tízéves kutatási ciklus elméleti és empirikus összegzése jelent meg az RKK gyơri mühelyében: Rechnitzer János és munkatársainak térszerkezeti vizsgálódásai, a térszerkezetet alakító innovációk típusainak és területi terjedésének elemzései adják e kötet anyagát, s a szerző, aki talán a hazai innovációkutatások egyik legtöbbet publikáló személyisége, impozáns részletességgel ismerteti a téma nemzetközi irodalmát illetve elméleti hátterét.

Rechnitzer a bevezető, elméleti fejezetben elegáns áttekintéssel szolgál az innovációk térbeli megjelenésére és terjedésére vonatkozó külföldi kutatások széles köréröl. Schumpeter (1912-ben publikált) fejlödéselméleti alapmüvére hivatkozva a termelési technikai változások, az új termékek és tevékenységek illetve új szervezetek-kezdeményezések megjelenését a vállalkozási aktivitás motivációival magyarázza, kitérve arra is, hogy az új ötletek, új szervezetek, új közösségi viselkedési módok és motivációk milyen társadalmi és gazdasági feltételrendszer esetén változtatják meg a társadalmi megújulási érzékenységet, milyen döntésekre épülve képesek befolyásolni egyes települések, térségek, régiók alkalmazkodási hajlandóságát. Értelmezése szerint az innovációk konkrét formái a gazdasági-szervezeti, a termelési és tevékenységi, valamint a társadalmipolitikai megújulások folyamatában jelennek meg, amelynek átlátása megkívánja, hogy a gazdasági változások és a térségi fejlődés közötti összefüggéseket egyrészt makroökonómiai fejlödési hullámok, másrészt mikroökonómiai termelési ciklusok idődimenzióiban hasonlítsuk össze.

A kötet elsô nagyobb fejezetében Rechnitzer a termékéletciklusok és a térségfejlődés összefüggéseit világítja meg Schumpeter, Kondratyev, Hägerstrand, illetve Barta Gy., Lackó L. és Nikodémus A. munkáira hivatkozva. Kiemeli írásaikból azt a folyamatot, amelyben bizonyíthatóan a dinamikus vállalkozók által megvalósított innováció lesz okozója, ösztönzője a gazdasági ciklusoknak, illetve hatásuk mint az innovációk térbeli terjedésének egyik oka szerepel. Fontos ebben a folyamatban a területi differenciálódás, a regionális átrendeződés, amelynek során a centrumokból a perifériákra helyeződnek át az innovatív tevékenységek hatásai és maga az innovációs igény számos formája is. A kötet egyes fejezeteiben kimutatja, hogy az újdonságok keletkezése nincs feltétlenül a magterületek agglomerációjához kötve, de a centrumokban (s legfóképpen a fóvárosban illetve körzetében, valamint a nagyvárosokban) szükségképpen koncentráltabban találhatjuk meg az erőteljesebb innovációs törekvéseket, lévén hogy ott inspiratívabb a gazdasági környezet, kedvezöbbek a települési és munkaerôpiaci feltételek, sokoldalúbbak az információk és a szakképzettségi mutatók, vagyis az egész innová- 
ciós miliỏ gazdagabb. Ugyanakkor a településhálózat történeti tagoltsága illetve ipari és infrastrukturális ellátottsága minden eredendó elmaradottsága dacára a perifériákon is jelentős innovációs forrás lehet, lévén sokkal nagyobb szüksége van a megújulásra, a telítetlen piacok feltöltésére, a szakképzetlenebb, de olcsóbb munkaeró hasznosítására. A perifériák dinamikus fölfejlődésének problémáját viszont strukturálisan akadályozta Magyarországon, hogy bár a hazai regionális iparszerkezetben a termelési kapacitások perifériára kihelyezésével jelentős eltolódás következett be a korábbi túlcentralizáltsághoz képest, azonban mindez nem járt együtt a termelés irányitásának decentralizálásával, a gazdálkodás különböző szintjeinek helyi alakításával, a döntési jogosítványok helybeli gyakorlásával és a helyi gazdasági-müszaki menedzsment kialakításának lehetőségével - ami éppen a rendszerváltás éveiben, a keleti piacok elveszitése és a privatizáció megindulása idején jelentkezett élesen a tervgazdaság látszólag kiegyensúlyozott térségi politikájához képest.

Rechnitzer okkal hangsúlyozza, hogy a területi differenciálódás folyamatában a térbeli struktúrák megváltoznak, a központi régió növekedése, stagnálása és hanyatlása a térbeli innovációk átrendeződését és lassú periferizálódását eredményezi. Ennek azonban csak akkor nincs kényszerítỏen kellemetlen hatása, ha a regionális potenciálok, a helyi önszervezödések, a civil társadalom válaszai pozitívan reagálnak a kihívásokra, vagyis ha a regionális erőforrások és szocioökonómiai tényezők hajlamosnak mutatkoznak az innovációs hullámok befogadására, hasznositására. Következőleg az innovációk hullámgörbéi, diffúziós hatásai serkenthetik az innovációorientált regionális politikát, de mind az állami, központi, mind a lokális, regionálishelyi kormányzatok feladatait kihívások formájában inspirálniok kell, ellenkezö esetben nemhogy európai felzárkózási álmokat nem dédelgethetünk, de számolnunk kell a leszakadás mellett a szétszakadás, a területi dezintegráció vélhetően visszafordíthatatlan következményeivel is. A szerzó úgy látja, hogy a hierarchikus és a szomszédsági diffúziók, az innovációk terjedésének intézményes és perszonális útjai hozzárendelhetők bármilyen területi struktúrához, s éppen ezért van nagy szükség a regionális gazdaságtanra, arra, hogy a terjedési minták ismeretében a térbeli mozgáspályákat növelni, szélesíteni segítsen egy új térségi szemléletmód kialakításával.

A kötet gondolatilag impozánsan felépített szerkezetén belül a szerzó lényegében sorra veszi az innovációk típusait, magyarországi megjelenésüket és terjedési mutatóikat, illusztrálja a gazdasági-szervezeti innovációk, a vállalkozások térségi megjelenését, sorra veszi a privatizáció folyamatának máris tettenérhetó területi összefüggéseit, a városhálózat innovációs mutatóit, a regionális potenciálok megjelenését és irányait, a humántőke és a vállalkozói környezet inspirálására alkalmas területeket. Különösen izgalmas, ahogy kutatásaira alapozva kimutatja a világútlevelek, a személygépkocsi-értékesítő hálózatok, valamint a számítógépek elterjedésének, vagyis konkrét innovációs törekvéseknek térszerkezeti sajátosságait, $\mathrm{s}$ kitér a „vidék” szerepére a gazdaságipolitikai átmenet korszakában, különös figyelemmel a politikai aktivitás regionális 
különbségeire és a civil társadalom önszervező erőinek megjelenésére, intézményesülésére, és településtípusonkénti illetve tảjegységi adottságaira.

A hazai területi politika a magánszféra intézményes korlátozására, a helyi törekvések paternalista kezelésére, a kezdeményezések becsatornázására állt be, az erőforrásokat a településhálózat városi szintjein koncentrálta és kezelte. Ezzel a lokális centrumokban megnövekedett potenciállal, amelyet különösen a polgári hagyományokat erőteljesebben örzó telepulések tudtak konzerválni, a hazai területi politika még a piacgazdaság elemeinek megjelenése idején sem tudott mit kezdeni. A kormányzati politika a lehetséges erőforrások java részét a válságtérségekbe koncentrálja, további erós fủggőségi kapcsolatokat kiépitve a centrum és a perifériák között. A növekedés-orientált regionális fejlesztések többek között ezért is szembekerülnek olykor a minöségi innovációs aktivitásokkal; az új regionális fejlesztéseknek tehát posztmodern fejlesztési stratégiákkal kell kủzdeniük azért, hogy a szerkezeti problémákkal kủszködő centrumok átalakítása és a perifériákon meglévő új és régi értékek aktivizálása, revitalizálása segítségével ne csak a merev megyerendszeri, s ne csak az elavuló nemzetgazdasági cselekvési pályák változzanak meg, hanem a nagytérségi vagy makroregionális erỏforrásokat, az endogén fejlesztési potenciálokat figyelemmel kísérö területfejlesztés lehessen a jövő útja.

Rechnitzer János tanulmányai a szakmai közönség előtt jól ismertek, hivatkozottak, sokféleképp vitatottak és értelmezettek. A recenzens itt nem is vállalhatja, hogy a maga szakterülete felöl kritikai kifogásokat fogalmazzon meg (példaképp a társadalmi átrétegződés területi következményeinek, a munkamegosztási áttagolódás és a térségi munkaerő-gazdálkodás konfliktusos állapotainak, a határmentiség jelentőségének vagy a magyar társadalom kulturálisvallási-etnikai tagoltságából származó térségi eltéréseknek jelentőségét szivesen olvastam volna a szerzỏ tollából). Ennél fontosabbnak látszik viszont az, hogy a kötet (az egyébként nem egykönnyen hozzáférhetỏ szakmai publikációkat összefüggő szerkezetben tálalva) a nagyobb nyilvánosság számára is elérhetö formában rendkívül fontos társadalomgazdasági, régiótörténeti, térföldrajzi és mentalitásbeli vonásokkal gazdagítja ismereteinket, $\mathrm{s}$ olyasmire hívja föl a figyelmet, amellyel túlzások nélkül állítható - a társadalom- és a településtudományok mủvelőinek, a humán erőforrások és a gazdasági innovációk kutatóinak, végsö soron külföldi vállalkozóknak és magyar bankároknak, ágazati fejlesztőknek és munkaerőpolitikai tervezöknek is (stb.) komoly leckét ad fel. Kihívása egyúttal válasz is arra, hogy a szétszakadás és a felzárkózás esélyei kőzül a szerző melyik utat választaná és az azon lehetséges elindulást milyen módon képzeli el: könyve ritkán átlátható összefüggésekről, folyamatokról és megoldásokról szól, amelyek nélkül aligha érthetőek meg a nálunk különösen a rendszerváltás folyamatában intenzívvé vált területi politikák.

A. Gergely András 